MATHEMATICAL ASSOCIATION

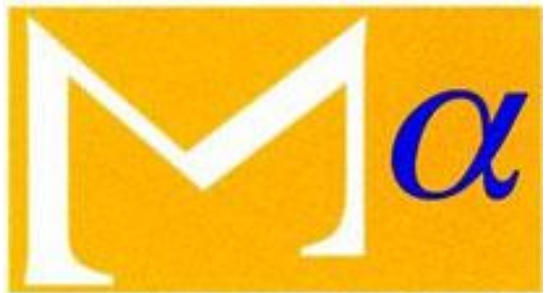

supporting mathematics in education

Some Incidental Writings by De Morgan

Author(s): A. De Morgan

Source: The Mathematical Gazette, Vol. 9, No. 129 (May, 1917), pp. 78-83

Published by: Mathematical Association

Stable URL: http://www.jstor.org/stable/3603501

Accessed: 13-01-2016 22:35 UTC

Your use of the JSTOR archive indicates your acceptance of the Terms \& Conditions of Use, available at http://www.jstor.org/page/ info/about/policies/terms.jsp

JSTOR is a not-for-profit service that helps scholars, researchers, and students discover, use, and build upon a wide range of content in a trusted digital archive. We use information technology and tools to increase productivity and facilitate new forms of scholarship. For more information about JSTOR, please contact support@jstor.org. 


\section{SOME INCIDENTAL WRITINGS BY DE MORGAN.}

WHILE gathering the materials for something in the nature of a "Companion " to De Morgan's " Budget of Paradoxes," I came across a considerable number of his notes, short papers, and other contributions to the famous English periodical known as "Notes and Queries." The first number appeared on Nov. 3, 1849, and from that date "N. \& Q." has been a household word among those who are afflicted with the insatiable desire to penetrate into the bye-ways of Literature, Genealogy, Heraldry, Antiquarian Lore, the Science of History and the History of Science-all formed grist for those who came to that mill. By the kind permission of the Editor of this invaluable publication, I have been permitted to reproduce from its columns what is presented to the reader in the following pages. The early numbers of " $\mathrm{N}$. \& Q." are exceedingly scarce, and a complete set is hardly to be obtained by those who live at a distance from the great libraries.

Those who find the following extracts amusing and instructive will perhaps bear in mind how useful a medium " $\mathrm{N}$. \& Q." is for enquiries in almost every field of literature and science. It has an advantage over the Gazette in at least one respect-it is a weekly, and answers may reach enquirers after a much shorter interval than is possible in our case. But there is no need to dwell further on the merits of "N. \& Q." What is important, is that the Editor of that periodical should know that the readers of the Gazette, as well as the writer of those lines, are grateful for his instant and generous consent to a request for permission to extract such communications as it received from De Morgan in the first decade or so of its existence.

The communications to "N. \& Q." are for the most part signed "M." or with the name in full. There are a few which from internal evidence may be attributed to De Morgan, and I have found one in which identity is concealed under a numerical signature.

They are not all on mathematical subjects. They include replies to questions on the variety of topics likely to be raised in such a periodical as "N. \& Q." But they are almost all on matters of common interest, and reveal the wide culture and omnivorous reading of one to whom books were as the salt of life. De Morgan did not always "suffer fools gladly," and his excursions into the field of dialectic are characterised by much pretty play with the rapier, with occasionally an exhibition of the skilful use of the bludgeon or quarter-staff. At any rate, in so far as they show the play of an alert and vigorous intellect, and a devotion to ethical principle, they are too good to be lost. I have borne in mind the needs of the younger reader, and where names, books, and references now unfamiliar to the average person are introduced I have ventured, as far as my own reading and distance from large libraries permitted, to add many notes, titles of books referred to, and quotations of interest, especially from other writings of $\mathrm{De}$ Morgan. It is hoped that no apology is needed for this. Many of the names of men are those of half-forgotten worthies, who in their day played their part gallantly enough, and by no means deserve the total or partial oblivion with which they are threatened.

All students of the History of Mathematics should possess themselves of the remarkable Catalogues issued by Messrs. Sotheran under the title, Bibliotheca Chemico-Mathematica. They are of great intrinsic interest, and I believe them to be deserving of almost implicit confidence. Hereinafter I refer to them as "S." They are worthy of a firm which has been in existence for over a century. 
The context will sufficiently indicate the notes occasionally added to queries, etc., by the Editor of "N. \& Q." This was the antiquary, William John Thoms (1803-1885), deputy librarian to the House of Lords. He founded "N. \& Q." in the year 1849.

D. N.B. refers to the Dictionary of National Biography; N.E.D. to the great Oxford Dictionary.

All material not directly from " N. \& Q." is placed in square brackets. I. i. 281 is De Morgan's own proposed notation for Series I. volume i. p. 281.

Additional notes, corrections, and suggestions will be welcomed by the compiler. One must cover almost the whole field of knowledge to do De Morgan full justice.

1849. I. i. 107. Boswell's Arithmetic.-[This query is headed "Dr. Johnson and Professor de Morgan," and is answered in the course of De Morgan's reply to another query, I. viii. 198.]-Mr. Editor,Although your cleverly conceived publication may be considered as more applicable to men of letters than to men of figures, yet I doubt not you will entertain the subject I am about to propound : because, in the first place, "whole generations of men of letters" are implicated in the criticisms ; and, in the next place, because however great, as a man of figures, the critic may be, the man of letters criticised was assuredly greater.

Professor de Morgan has discovered a flaw in the great Johnson! and, in obedience to your epigraph, "when found make a note of it," he has made a note of it at the foot of p. 7 of The Companion to the Almanac for 1850,-eccola :-

"The following will show that a palpable absurdity will pass before the eyes of generations of men of letters without notice. In Boswell's Life of Johnson (chapter viii. of the edition with chapters), there is given a conversation between Dr. Adams and Johnson, in which the latter asserts that he could finish his Dictionary in three years.

"Adams. 'But the French Academy, which consists of forty members, took forty years to compile their Dictionary.' Johnson. 'Sir, thus it is. This is the proportion. Let $m \theta s e \theta$ : forty times forty is sixteen hundred, so is the proportion of an Englishman to a Frenchman.'

"No one of the numerous editors of Boswell has made a note upon this, although many things as slight have been commented upon : it was certainly not Johnson's mistake, for he was a clear-headed arithmetician. How many of our readers will stare and wonder what we are talking about, and what the mistake is !"

Certes, I for one, plead guilty to staring, and wondering what the Professor is talking about.

I cannot for a moment imagine it possible, that he could base such a criticism, so announced, upon no better foundation than the mere verbal transposition of the words Englishman and Frenchman.

The inversion deceives no person, and it is almost more appropriate to the colloquial jocularity of the great Lexicographer's bombast than if the enunciation had been more strictly according to rule. Besides, the correctness of the expression, even as it stands, is capable of defence. Let the third and fourth terms be understood as referring to time instead of to power, and the proportion becomes "as three to sixteen hundred so is " (the time required by) "an Englishman to " (that required for the same work by) "a Frenchman."

Or, if natives be referred to in the plural,- - then, as three to sixteen hundred, so are Englishmen to Frenchmen ; that is, such is the number of each required for the same amount of work. 
But I repeat that I cannot conceive a criticism so trifling and questionable can have been the true aim of Professor de Morgan's note, and as I am unable to discover any other flaw in the Doctor's proportion, according to the premises, my query, Mr. Editor, has for its object to learn

\section{"What the mistake is?"}

B.

[What Boswell really gave was : "Let me see; forty times forty is sixteen hundred. As three to sixteen hundred, so is the proportion of an Englishman to a Frenchman," $v$. Vol. I. c. v. p. 99 (Routledge, edn. in 4 vols.). For another " jolly confusion of ideas," from "Tristram Shandy," v. 3, ef. The Budget of Paradoxes (hereinafter referred to as The Budget), pp. 417-418 (1872).]

I. viii. 198. A. E. B. quoting from the Companion to the Almanac for 1850 , p. 9 , cites De Morgan's remark, explaining the usage of attainment of majority :

"Nevertheless in the law, which here preserves the old reckoning, he is of full age on the 9th : though he were born on the 10th, he is of age to execute a settlement a minute after midnight on the morning of the 9th." This statement clashes with that in the opening scene of Ben Jonson's Staple of News, where Pennyboy jun. counts as his watch strikes one, two, three... six !

$$
\begin{aligned}
& \text { "Enough, enough, dear watch, } \\
& \text { Thy pulse hath beat enough } \\
& \text {-The hour is come so long expected," \&c. }
\end{aligned}
$$

Then the "fashioner" comes in to fit on the heir's new clothes; he had waited below 'till the clock struck, and gives, as an excuse, "your worship might have pleaded nonage, if you had got 'em ere I could make just affidavit of the time."

A. E. B. asks how the two statements can be reconciled, seeing that these "particulars are too verbatim to admit of doubt as to the peculiar usage of that time."

De Morgan replies, p. 250 :

Attainment of Majority.-A. E. B. has not quoted quite correctly. He has put two phrases of mine into Italics, which makes them appear to have special relation to one another, while the word which $I$ put in Italics, "ninth," he has made to be "9th." Farther, he has left out some words. The latter part should run thus, the words left out being in brackets :

". . . though he were born [a minute before midnight] on the 10 th, he is of age to execute a settlement at a minute after midnight on the morning of the 9th, forty-eight hours all but two minutes before he has drawn breath for the space of twenty-one years."

Had the quotation been correct, it would have been better seen that I no more make the day of majority begin a minute after midnight, than I make the day of birth end a minute before midnight. A second, or even the tenth of a second, would have done as well.

The old reckoning, of which I was speaking, was the reckoning which rejects fractions; and the matter in question was the day. For my illustration, any beginning of the day would have done as well as any other ; on this I must refer to the paper itself. Nevertheless, I was correct in implying that the day by which age is reckoned begins at midnight; and I. believe it began at midnight in the time of Ben Jonson. The law recognised two kinds of days; - the natural day of twenty-four hours, the artificial day from sunrise to sunset. The birthday, and with it the day of majority, would needs be the natural day; for otherwise a child not born by daylight would have no birthday at all. I cannot make out that the law ever recognised a day of twenty- 
four hours beginning at any hour except midnight. For payment of rent, the artificial day was recognised, and the tenant was required to tender at such time before sunset as would leave the landlord time to count the money by daylight; a reasonable provision, when we think upon the vast number of different coins which were legal tender. But even here it seems to have been held that though the landlord might enter at sunset, the forfeiture could not be enforced if the rent were paid before midnight. A legal friend suggested to me that perhaps Ben Jonson had more experience of the terminus of the day as between landlord and tenant, than of that which emancipates a minor. This would not have struck me : but a lawyer views man simply as the agent or patient in distress, ejectment, quo warranto, \&c.

A. E. B. twice makes the question refer to usage, whereas I was describing law. If I were as well up in the drama as I should like to be, I might perhaps find a modern plot which turns upon a minor coming of age, in which the first day of majority is what is commonly called the birthday, instead of, as it ought to be, the day before. Writers of fiction have in all times had fictitious law. If we took decisions from the novelists of our own day, we should learn, among other things, that married women can in all circumstances make valid wills, and that the destruction of the parchment and ink which compose the material of a deed is also the destruction of all power to claim under it.

Singularly enough, this is the second case in which my paper on reckoning has been both misquoted and misapprehended in "N. \& Q." My knowledge of the existence of this periodical began with a copy of No. 7 (containing p. 107, vol. i.), forwarded to me by courtesy of the Editor, on account of a Query signed (not A. E. B. but) B., affirming that I had "discovered a flaw in the great Johnson !" Now it happened that the flaw was described, even in B.'s own quotation from me, as " certainly not Johnson's mistake, for he was a clear-headed arithmetician." B. gave me half a year to answer ; and then, no answer appearing, privately forwarded the printed Query, with a request to know whether the readers of "N. \& Q." were not of a class sufficiently intelligent to appreciate a defence from me. The fact was, that I thought them too intelligent to need it, after the correction (by $\mathrm{B}$. himself, in p. 127) of the misquotation. It is not in letters as in law, that judgment must be signed for the plaintiff if the defendant do not appear. There is also an anonymous octavo tract, mostly directed, or at least (so far as I have read) much directed, against the arguments of the same article, and containing misapprehensions of a similar kind. That my unfortunate article should be so misunderstood in three distinct quarters, is, I am afraid, sufficient presumption against its clearness; and shows me that obscurus fio is, as much as ever, the attendant of brevis esse laboro: but I am still fully persuaded of the truth of the conclusions.

A. De Morgan.

On p. 296 of the same volume A. F. B. quotes from " a black letter octavo" entitled A Concordancie of Yeares, published in 1615 (and for that year), chap. xiii. :

"The day is of two sorts, natural and artificiall : the natural day is the space of 24 hours, in which time the sunne is carried by the first Mover, from the east into the west, and so round about the world into the east againe."

"The artificiall day continues from sunne-rising to sunne-setting: and the artificiall night is from the sunne's setting to his rising. And you must note that this natural day, according to divers, hath divers beginnings: As the Romanes count it from mid-night to mid-night, because at that time our Lorde was borne, being Sunday; and so do we account it for fasting dayes. The Arabians begin their day at noone, and end at noone the next day; for because they say the sunne was made in the meridian; and so do all astro- 
nomers account the day, because it alwayes falleth at one certaine time. The Umbrians, the Tuscans, the Jewes, the Athenians, Italians, and Egyptians, do begin their day at sunne-set, and so do we celebrate festivall dayes. The Babylonians, Persians, and Bohemians begin their day at sunne-rising, holding till sunne-setting ; and so do our lawyers count it in England."

The author quoted is Arthur Hopton, "a distinguished mathematician, a scholar of Oxford, a student in the Temple"; and the volume itself is dedicated to "The Right Honourable Sir Edward Coke, Knight, Lord Chiefe Justice of England," \&c.

Mr. Russell Gole writes (p. 371): The misunderstanding which has arisen between Professor De Morgan and A. E. B. has proceeded, it appears, from the misapplication of the statement of the latter's authority (Arthur Hopton) to the question at issue. Where Hopton says that our lawyers count their day from sunrise to sunset, he, I am of opinion, merely refers to certain instances, such as distress for rent :

"A man cannot distrain for rent or rent-charge in the night (which, according to the author of The Mirror, is after sunset and before sunrising)."-Impey on Distress and Replevin, p. 49.

In common law, the day is now supposed among lawyers to be from six in the morning to seven at night for service of notices ; in Chancery, till eight at night. And a service after such times at night would be counted as good only for the next day. In the case of Liffin $v$. Pitcher, 1 Dowl. N.S. 767., Justice Coleridge said, "I am in the habit of giving twenty-four hours to plead when I give one day." Thus it will be perceived that a lawyer's day is of different lengths.

With regard to the time at which a person arrives at majority, we have good authority in support of Professor De Morgan's statement :

" So that full age in male or female is twenty-one years, which age is completed on the day preceding the anniversary of a person's birth, who till that time is an infant, and so styled in law."-Blackstone's Commentaries, vol. i. p. 463 .

There is no doubt also that the law rejects fractions of a day where it is possible :

"It is clear that the law rejecteth all fractions of days for the uncertainty, and commonly allows him that hath part of the day in law to have the whole day, unless where it, by fraction or relation, may be a prejudice to a third person."-Sir O. Bridgm. 1 .

And in respect to the present case it is quite clear. In the case of Reg. $v$. the Parish of St. Mary, Warwick, reported in the Jurist (vol. xvii. p. 551), Lord Campbell said :

"In some cases the Court does not regard the fraction of a day. Where the question is on what day a person came of age, the fraction of the day on which he was born and on which he came of age is not considered."

And farther on he says :

"It is a general maxim that the law does not regard the fraction of a day."

Prof. De Morgan sums up the discussion at this point (p. 372): I only treat misquotation as an offence in the old sense of the word; and courteously, but most positively, I deny the right of any one who quotes to omit, or to alter emphasis, without stating what he has done. That A. E. B. did misunderstand me, I was justified in inferring from his implication that I made the day begin " a minute after midnight."

Arthur Hopton, whom A. E. B. quotes against me (but the quotation is from chapter xiv., not xiii.), is wrong in his law. The lawyers, 
from Coke down to our own time, give both days, the natural and artificial, as legal days. See Coke Littleton (Index, Day), the current commentators on Blackstone, and the usual law dictionaries.

Nevertheless, this discussion will serve the purpose. No one denies that the day of majority now begins at midnight: no one pretends to prove, by evidence of decisions, or opinions of writers on law, that it began otherwise in 1600. How then did Ben Jonson make it begin, as clearly as A. E. B. shows he does, at six o'clock (meaning probably a certain sunrise) ? Hopton throws out the natural day altogether in a work on chronology, and lays down the artificial day as the only one known to lawyers : it is not wonderful that Jonson should have fallen into the same mistake.

A. De Morgan.

[An elaborate reply by A. E. B. will be found on pp. 571-3 of the same volume, after which the subject seems to have dropped.j

I. x. 363. Boswell's Arithmetic.-I once pointed out a mistake which Boswell had fixed on Johnson. The curiosity is, not that Boswell should have blundered, but that so many editors should have allowed the blunder to pass. I now point out another such mistake, and submit it for correction.

"Boswell. I wish to have a good walled garden.

"Johnson. I don't think it would be worth the expense to you. We compute, in England, a park wall at a thousand pounds a mile; now a garden wall must cost at least as much. You intend your trees should grow higher than a deer will leap. Now let us see; for a hundred pounds you could only have forty-four square yards, which is very little; for two hundred pounds you may have eighty-four [eighty-eight of course] square yards, which is very well."-Boswell's Johnson, aetat. 74, vol. viii. p. 195 of Croker's tenvolume edition.

On this there is one commentator, according to Mr. Croker, namely, the Bishop of Ferns (Dr. Elvington, the editor of Euclid, I suppose). The Bishop says that Boswell makes Johnson talk nonsense, and that it ought to be fourty-four yards square instead of fourty-four square yards. This makes the matter worse. I think I see how the confusion arose in Boswell's mind, but at present I leave it as a Query.

\section{(To be continued.)}

A. De Morgan.

\section{MATHEMATICAL NOTES.}

\section{8. [K. 8. a.] Brocard Points for a Quadrilateral.}

If a point $X$ can be found within a cyclic quadrilateral $A B C D$, such that the angles $X A D, X B A, X C B, X D C$ are equal, then

$$
B C . A D=D C . A B \text {. }
$$

Let $A B C D$ be the quadrilateral ; denote the sides $B C, C D, D A, A B$ by a, $b, c, d$; the diagonals $D B, A C$ by $e, f$; the area by $Q$; the circum-radius by $R$ and each of the angles $X A D, X B A, X C B, X D C$ by $\omega$. Then

$$
\begin{aligned}
& \angle A X B=\pi-\omega-(A-\omega)=\pi-A \text {. } \\
& \text { Similarly } \quad \angle B X C=\pi-B, \angle C X D=\pi-C, \angle D X A=\pi-D \text {. } \\
& \text { Now } \\
& \frac{A X}{\sin \omega}=\frac{d}{\sin A X B}=\frac{d}{\sin (\pi-A)}=\frac{d}{\sin A} \\
& \frac{A X}{\sin (D-\omega)}=\frac{c}{\sin A X D}=\frac{c}{\sin (\pi-D)}=\frac{c}{\sin D} \\
& \therefore \frac{\sin (D-\omega)}{\sin \omega}=\frac{d \sin D}{c \sin A} \text {, or } \cot \omega=\frac{d}{c} \operatorname{cosec} A+\cot D \text {. }
\end{aligned}
$$

